\title{
Gastrointestinal tract cancers: Genetics, heritability and germ line mutations (Review)
}

\author{
XIAO-PENG LV

\begin{abstract}
Xuzhou Central Hospital, Xuzhou Clinical School of Xuzhou Medical College, The Affiliated Xuzhou Hospital
\end{abstract} \\ of Medical College of Southeast University, Xuzhou, Jiangsu 221009, P.R. China
}

Received October 7, 2016; Accepted November 21, 2016

DOI: $10.3892 / \mathrm{ol} .2017 .5629$

\begin{abstract}
Gastrointestinal (GI) tract cancers that arise due to genetic mutations affect a large number of individuals worldwide. Even though many of the GI tract cancers arise sporadically, few of these GI tract cancers harboring a hereditary predisposition are now recognized and well characterized. These include Cowden syndrome, MUTYH-associated polyposis, hereditary pancreatic cancer, Lynch syndrome, Peutz-Jeghers syndrome, familial adenomatous polyposis (FAP), attenuated FAP, serrated polyposis syndrome, and hereditary gastric cancer. Molecular characterization of the genes that are involved in these syndromes was useful in the development of genetic testing for diagnosis and also facilitated understanding of the genetic basis of GI cancers. Current knowledge on the genetics of GI cancers with emphasis on heritability and germ line mutations forms the basis of the present review.
\end{abstract}

\section{Contents}

1. Introduction

2. Hereditary CRC syndromes

3. CRC syndromes with adenomatous polyps

4. Hamartomatous polyposis syndromes

5. Conclusion

\section{Introduction}

Cancers arising within the gastrointestinal (GI) tract are genetic disorders caused by the sequential accumulation of alterations in genes that control the growth, differentiation,

Correspondence to: Dr Xiao-Peng Lv, Xuzhou Central Hospital, Xuzhou Clinical School of Xuzhou Medical College, The Affiliated Xuzhou Hospital of Medical College of Southeast University, 199 Jiefang South Road, Xuzhou, Jiangsu 221009, P.R. China

E-mail: rqxjdymui8201@163.com

Key words: genetics, heritability, gastrointestinal cancers, mutations and DNA repair (1). Although the majority of cases appear to arise sporadically, a small percentage of GI cancers have an apparent hereditary component, as evidenced by the well-characterized genetic syndromes and the family history associated with the high risk of these syndromes (2). Nearly $5 \%$ of inherited cases are due to highly penetrant mutations with well characterized clinical presentations (3). An additional 20-25\% of cases are estimated to have an associated hereditary component, which has not yet been established (4). Many of the GI tract cancers appear to be due to mutations in single genes and these types of cancer are less penetrant but occur more frequently as compared to the cancers seen in combination with well-characterized syndromes (1). Examples for single gene mutations include common single-nucleotide polymorphisms (SNPs) in genes that are involved in the control of metabolism or which are regulated by environmental factors (4). Mutations in multiple susceptibility loci can also lead to these cancers by inducing additive effects (2). Identification of individuals who are at risk for GI tract cancer, and the development of methods for better diagnosis and prevention of cancer and therapeutic approaches is dependent on proper understanding of the molecular basis and genetics of GI tract cancers (3).

The present review addresses the genetics of the currently well-characterized hereditary cancers of GI tract. In this review we focus on the genetics of hereditary GI cancers, which are primarily that of a type of colorectal cancer (CRC) syndromes and also briefly discuss some aspects of pancreatic, and stomach cancers.

\section{Hereditary CRC syndromes}

Clinical, pathological, and genetic features form the basis for identifying and classifying the CRC syndromes. Pathophysiological conditions that lead to adenomatous polyps include familial adenomatous polyposis (FAP), attenuated FAP (AFAP), MUTYH-associated polyposis (MAP) and Lynch syndrome. Hamartomatous polyps are the primary lesions in Peutz-Jeghers syndrome (PJS) and juvenile polyposis syndrome (JPS) (5). Serrated polyposis syndrome (SPS) is unique situation as it poses much higher cancer risk and therefore this syndrome needs to be identified separately from other conditions. Except for MAP, all these abovementioned conditions are inherited autosomal dominant disorders. MAP 
Table I. Mode of inheritance of non-polyposis syndrome as well as the associated genes, lifetime risk of cancer development and non-malignant features.

\begin{tabular}{|c|c|c|c|c|c|}
\hline Syndrome & Inheritance & Gene & Sites & Lifetime risk (\%) & Non-malignant features \\
\hline $\begin{array}{l}\text { Lynch } \\
\text { syndrome }\end{array}$ & $\begin{array}{l}\text { Autosomal } \\
\text { dominant }\end{array}$ & $\begin{array}{l}h M L H 1 \\
h M L H 2 \\
h M L H 6 \\
h P M S 2 \\
\text { EpCAM } \\
\text { EpCAM }\end{array}$ & $\begin{array}{l}\text { Colon } \\
\text { Endometrium } \\
\text { Stomach } \\
\text { Ovary } \\
\text { Hepatobiliary tract } \\
\text { Upper urinary tract } \\
\text { Pancreas } \\
\text { Small bowel } \\
\text { CNS }\end{array}$ & $\begin{array}{c}50-80 \\
40-60 \\
11-19 \\
9-12 \\
2-7 \\
4-5 \\
3-4 \\
1-4 \\
1-3\end{array}$ & $\begin{array}{l}\text { Physical or non-malignant features, with the } \\
\text { exception of keratoacanthomas and } \\
\text { sebaceous adenomas/carcinomas, are rare }\end{array}$ \\
\hline
\end{tabular}

hMLH, human mutL homolog; hPMS2, human postmeiotic segregation 2; CNS, central nervous system.

is autosomal recessive, whereas, SPS is rarely inherited. There are many similarities between the phenotypes of AFAP and MAP, which are associated with varying numbers of adenomas, and these also resemble the phenotypes of Lynch syndrome, sporadic polyps, and other polyposis syndromes, often causing some confusion (6). Despite the clinical similarities between these syndromes, each of them has unique genetic aetiologies and cancer risks, and also specific clinical features.

\section{CRC syndromes with adenomatous polyps}

Conditions that express adenomatous polyps are seen only in a few of the inherited GI cancer predisposition syndromes, such as Lynch syndrome, FAP, AFAP, and MAP. The chances of developing colon cancer and tumors elsewhere are quite high in these syndromes (7) and non-malignant manifestations seen in these syndromes contribute to elevated morbidity and mortality.

Lynch syndrome. Lynch syndrome or hereditary non-polyposis colon cancer is one of the main causes for up to $5 \%$ of all CRC (8-10). Individuals with Lynch syndrome have an $80 \%$ risk for CRC (4). The syndrome is also associated with an increased risk of developing malignancies at extra-colonic sites such as endometrium, stomach, ovary, small bowel, pancreas, ureter, renal pelvis, hepatobiliary tract, and brain (11-14). Among these sites, cancer arising within endometrium is the second most common malignancy in Lynch syndrome with a lifetime risk between 40 and $60 \%$ (Table I), which is similar to or even higher than the estimated risk for CRC in women with Lynch syndrome. However, endometrial cancer often occurs before CRC in these women $(8,15,16)$. Approximately $2 \%$ of all endometrial cancers likely arise due to Lynch syndrome (17).

An important feature of Lynch syndrome is that there is an early onset of cancer as compared to the general population $(13,18)$. Thus, while in the general population, CRC has an onset at 65 years and endometrial cancer at 60 years, these onset ages are much lower in people with Lynch syndrome, at 44 and 48 years, respectively, for these two types of cancer (14,19-21). Lynch syndrome is also characterized by the occurrence of synchronous (multiple primary cancers occurring simultaneously) and metachronous (multiple cancers occurring at intervals) tumors $(22,23)$. Synchronous and metachronous cancers occur to different extents in individuals with Lynch syndrome (50\% incidence) as compared to those with sporadic CRC (20\% incidence) $(14,24)$. Furthermore, the right or proximal colon are frequent sites for CRC in Lynch syndrome patients, whereas in individuals with sporadic CRC, there is relatively higher incidence of sigmoid/distal carcinomas $(9,13,14,25)$. Crohn's-like reactions, tumor-infiltrating lymphocytes, signet ring cells and mucinous adenocarcinoma are some of the main pathologic features of CRC associated with Lynch syndrome. These pathological features, which are often considered as red flags for Lynch syndrome, are less common in sporadic CRC $(14,21,22,26)$. A high level of microsatellite instability (MSI-H), which is a feature of carcinogenic process when there is defective DNA mismatch, is also a characteristic of Lynch syndrome. Studies show that MSI-H-bearing colon cancers have better overall prognosis unlike the colon cancers without MSI (27).

Germline mutations in mismatch repair (MMR) genes, which are a special class of tumor suppressor genes that are responsible for correcting DNA errors that occur during replication, lead to the pathogenesis of Lynch syndrome (23). Genes recognized to be associated with Lynch syndrome include human mutL homolog $1(h M L H 1)$ at $3 \mathrm{p} 21.3$, human mutS homolog 2 (hMSH2) at 2p21-p22, hMSH3 at 5q11-q12, hMSH6 at 2p16 human postmeiotic segregation 1 (hPMSl) at $2 \mathrm{q} 31-\mathrm{q} 33$, and $h P M S 2$ at $7 \mathrm{q} 22$ (22). Almost $90 \%$ of the cases with Lynch syndrome arise due to mutations in $h M L H 1$ and $h M S H 2$, whereas a small number of cases $(10 \%)$ are thought to be due to mutations in $h M S H 6$ and only on rare occasions mutations in $h P M S 2$ are evident (28-31). Mutations in these genes show predominantly autosomal dominant inheritance with close to $80 \%$ penetrance for CRC and a $25 \%$ risk for metachronous CRC (14). These numbers are relatively lower for endometrial cancer (60\% penetrance) as well as for other cancers $(<20 \%)$. Observed phenotypic variations show dependency on the specific gene mutation. Thus, there is a slightly increased incidence of endometrial cancer in families with hMSH6 mutations who also show a moderately lower incidence of CRC compared with families harboring $h M L H 1$ 
Table II. Frequencies of tumors in patients with Lynch syndrome.

\begin{tabular}{lrrrrr}
\hline & \multicolumn{2}{c}{$\mathrm{h}$ MSH6 } & & \multicolumn{2}{c}{$\mathrm{h}$ MLH1/MSH2 } \\
\cline { 2 - 3 } Tumors & $\mathrm{n}$ & $\%$ & & $\mathrm{n}$ & $\%$ \\
\hline All primary tumors & 144 & - & & 859 & - \\
Colorectal cancer & 61 & 42.4 & & 563 & 65.5 \\
Endometrial cancer & 9 & 6.3 & & 43 & 5.0 \\
Ovarian cancer & 4 & 2.8 & & 12 & 1.4 \\
Stomach cancer & 10 & 6.9 & & 37 & 4.3 \\
Breast cancer & 8 & 5.6 & & 17 & 2.0 \\
Lung cancer & 7 & 4.9 & & 5 & 0.6 \\
Prostate cancer & 4 & $2-8$ & & 6 & $0-7$ \\
Cancer of renal & 0 & 0 & & 13 & 1.5 \\
pelvis and ureter & & & & \\
\hline
\end{tabular}

MSH6, mutS homolog 6; MLH1, mutL homolog 1; MSH2, mutS homolog 2 .

Table III. Penetrance as HR and cumulative risk to 70 years of age for cancer based on gender.

\begin{tabular}{lllc}
\hline Cancer & Gender & HR $(95 \% \mathrm{CI})$ & $\begin{array}{c}\text { Risk, } \% \\
(95 \% \mathrm{CI})\end{array}$ \\
\hline CRC & Male & $5-2(2.8-9.7)$ & $20(11-34)$ \\
& Female & $5-2(2.8-9.7)$ & $15(8-26)$ \\
Endometrial & Female & $7-5(2.8-20.0)$ & $15(6-35)$ \\
& Male & $2.5(0.4-16.2)$ & $6(1-33)$ \\
Less frequent Lynch & Female & $2.5(0.5-12.6)$ & $6(1-25)$ \\
cancers & Male & $0.9(0.3-2.3)$ & $24(10-51)$ \\
Other cancers & Female & $1.5(0.8-3.1)$ & $27(15-48)$ \\
& Male & - & $25(16-48)$ \\
Any Lynch & Female & - & $32(21-53)$ \\
syndrome-associated & & & \\
cancer & & & \\
\hline
\end{tabular}

CRC, colorectal cancer; HR, hazard ratio; CI, confluence interval.

and $h M S H 2$ mutations (Table II) (32). However, hPMS2 mutation carriers display very different risk, which is $15-20 \%$ risk for CRC, $15 \%$ for endometrial cancer, and $25-32 \%$ for any Lynch syndrome-associated cancer (Table III) $(29,33)$. In comparison to other MMR genes, these risks are much lower.

FAP. FAP is the second most common inherited CRC syndrome and accounts for approximately $1 \%$ of all CRC. It is characterized by the emergence of hundreds to thousands of adenomatous polyps throughout the colorectum, usually beginning in late childhood or adolescence. If untreated, individuals with FAP in adolescence inevitably develop CRC by the age of 40 years. Therefore, the penetrance of this syndrome is $100 \%$. Even though polyps may appear as early as 16 years of age, diagnosis of CRC may be delayed until 36 years of age (34). Development of CRC is observed in approximately $7 \%$ of patients by 21 years of age whereas $95 \%$ develop CRC by age 50 .

Other types of cancer associated with FAP are duodenal cancer, thyroid cancer, medulloblastoma, bile duct cancer, and childhood hepatoblastoma (Table IV). Benign neoplasms associated with FAP are upper GI polyps, desmoids tumors, sebaceous and epidermoid cysts, osteomas, supernumerary teeth, and congenital hypertrophy of the retinal pigment epithelium (CHRPE) (35). Although desmoids tumors are classified as benign, they occur in approximately $10 \%$ of FAP patients and can result in major medical complications, including death (36). Indeed, complications from desmoid tumors are one of the leading causes of death in individuals with FAP who have had a prophylactic colectomy (37).

FAP arises as a consequence of a germline heterozygous mutation in the adenomatous polyposis coli $(A P C)$ gene, a tumor suppressor gene located on chromosome $5 \mathrm{q} 21$. Individuals who carry a germline pathogenic mutation in the $A P C$ gene eventually develop FAP. Despite being a rare disease, FAP has been considered as a good model for hereditary cancers and mutations in $A P C$ gene are a good example of the molecular pathogenesis of neoplasia (38). Indeed, as is the case for other tumor suppressor genes, $A P C$ gene inactivation occurs only after both alleles have been damaged due to mutations. In FAP, one allele is inherited in a mutated form. Adenoma formation is initiated when the second allele is damaged or lost by somatic event. Inasmuch as significant number of adenomas likely develop within $15-40$ years, it is quite possible that initiation of tumorigenesis can be triggered with just two hits. However, considering that only a small number of these adenomas progress to cancer, the presence of several additional mutations is probably necessary for this tumorigenesis $(39,40)$.

Autosomal dominant inheritance of APC mutation is common in many cases of FAP, even though few cases (15-20\%) appear to display de novo APC mutation. Patients with these types of mutations therefore do not present with a family history of the disease, but appear to have somatic mosaicism $(36,37)$. Acquired $A P C$ mutations are often seen in sporadic colorectal carcinomas and recent studies suggest that nearly $66 \%$ of all CRCs harbor the mutated APC gene. Over 800 APC germline mutations have been reported (39) with the vast majority associated with FAP being truncating or nonsense mutations, and typically insertion or deletion, leading to altered reading frame $(40,41)$.

The APC gene also has another mutation, APC $11307 \mathrm{~K}$, which appears mostly in individuals of Ashkenazi Jewish descent (42). The APC 11307K mutation is an indirect causative factor for CRC, through the formation of a weak spot in the $A P C$ gene, which is critical to the development of CRC (42). The APC $11307 \mathrm{~K}$ mutation is autosomal dominantly inherited and people with this mutation generally develop cancer around the age of 60 years $(43,44)$. The lifetime risk of CRC development in individuals with APC $11307 \mathrm{~K}$ gene mutation is much less than the risk associated with the other hereditary CRC syndromes, and is estimated to be $10-20 \%(45,46)$.

AFAP. AFAP is a variant of FAP and is also characterized by polyposis. However, in AFAP, the total number of polyps is 
Table IV. Mode of inheritance of adenomatous polyposis syndromes as well as gene, lifetime risk of cancer development and non-malignant features associated with these syndromes.

\begin{tabular}{|c|c|c|c|c|c|}
\hline Syndrome & Inheritance & Gene & Sites & $\begin{array}{l}\text { Lifetime } \\
\text { risk }(\%)\end{array}$ & Non-malignant features \\
\hline FAP & Autosomal dominant & $A P C$ & $\begin{array}{l}\text { Colon } \\
\text { Duodenum/periampullary } \\
\text { Stomach } \\
\text { Pancreas } \\
\text { Thyroid } \\
\text { Liver (hepatoblastoma) } \\
\text { CNS (medulloblastoma) }\end{array}$ & $\begin{array}{l}100 \\
4-12 \\
<1 \\
2 \\
1-2 \\
1-2 \\
<1\end{array}$ & $\begin{array}{l}100-1000 \text { of colorectal adenomas } \\
\text { Gastric fundic gland and duodenal } \\
\text { Adenomatous polyposis } \\
\text { CHRPE, epidermoid cysts, osteomas } \\
\text { Dental abnormalities } \\
\text { Desmoids tumors }\end{array}$ \\
\hline AFAP & Autosomal dominant & $A P C$ & $\begin{array}{l}\text { Colon } \\
\text { Duodenum/periampullary } \\
\text { Thyroid }\end{array}$ & $\begin{array}{l}70 \\
4-12 \\
1-2\end{array}$ & $\begin{array}{l}<100 \text { colonic adenomas }(0-100) \\
\text { Upper GI polyposis similar to FAP } \\
\text { Other non-malignant features are } \\
\text { rare in AFAP }\end{array}$ \\
\hline MAP & Autosomal recessive & MUTYH & $\begin{array}{l}\text { Colon } \\
\text { Duodenum }\end{array}$ & $\begin{array}{r}80 \\
4\end{array}$ & $\begin{array}{l}\text { Colonic phenotype similar to AFAP } \\
\text { Duodenal polyposis }\end{array}$ \\
\hline
\end{tabular}

FAP, familial adenomatous polyposis; AFAP, attenuated familial adenomatous polyposis; MAP, MUTYH-associated polyposis; CNS, central nervous system; CHRPE, congenital hypertrophy of the retinal pigment epithelium; APC, adenomatous polyposis coli; GI, gastrointestinal.

$<100$ (Table IV), and the polyps have a tendency to develop on the right side of the colon (22). Furthermore, the penetrance of AFAP appears to be lower than that of FAP, and AFAP patients have a delayed development of CRC, by approximately 12 years, compared to those with classic FAP (36).

AFAP may also result from splice-site mutations, which cause in-frame deletions of APC ORF (open reading frame) in a small number of patients and in most cases, genes with these mutations encode near full-length protein, providing an intuitive explanation for the weak attenuated phenotype. On the other hand, mutations in the 5 ' region of the $A P C$ gene, upstream of codon 157, appear to cause most cases of AFAP. How these mutations which potentially lead to truncation of the APC contribute to the development of cancer remains to be determined. This paradox may be explained by the fact that translation is reinitiated at an in-frame ATG, at codon 184, when a mutation upstream of codon 169 causes truncation and such internal initiation is facilitated by an internal ribosome entry site. The resulting protein is devoid of regions containing amino acid sequences required for homodimerization and nuclear export, suggesting that these functions are probably not crucial for APC function. The hypomorphic nature of the truncated APC may be the cause for the lower number of polyps.

MAP. Unlike the other polyposis syndromes, which show an autosomal dominant pattern, MAP shows autosomal recessive inheritance and is possibly restricted to single generation. There are multiple colonic polyps in MAP patients and often it is difficult to distinguish MAP from classical AFAP (43). It has been suggested that MAP is the real AFAP (44). MAP is now known to be associated with CHRPE, osteomas, duodenal adenomas, anomalies, and gastric fundic gland polyps, as well as desmoids tumors, which are considered to be hallmarks of FAP (47). There may be up to 500 colorectal polyps in MAP and these polyps tend to be mostly small tubular or tubulovillous adenomas with mild dysplasia and there may also be hyperplastic polyps. Even though adenomas seem to show a right colonic predisposition, tumorigenesis can occur throughout colorectum. At the time of diagnosis, which is generally at approximately 45 years of age, the number of adenomas is $<100$ in many MAP patients and by approximately 50 years of age these patients develop CRC (45-49).

MAP is caused by bi-allelic mutations in the MUTYH gene, which encodes a base excision repair protein and loss of this protein compromises base excision repair and results in CG-AT transversions in several genes, including $A P C$ and KRAS $(43,50,51)$. While germline $M U T Y H$ mutations appear to be potential causes for polyps and cancer predisposition, somatic MUTYH mutations may not have a significant role in the pathogenesis of colon cancer $(52,53)$. There is approximately $80 \%$ lifetime CRC risk for $M U T Y H$ mutation carriers (Table IV). The two most common MUTYH mutations are missense mutations Y179V and G396D (earlier labeled as Y165V and G382D, respectively), and occur in more than $80 \%$ of individuals of European ancestry with MAP (43,50,52,54-56). Other population-specific MUTYH mutations have been found (53). Nearly $90 \%$ of MAP patients in western populations have at least one of these mutations (53).

In $8-13 \%$ of patients with $>100$ adenomas, even though disease causing APC mutations are absent, bi-allelic MUTYH mutations are found and these mutations are also seen in $16-40 \%$ of patients without any FAP but with 15-99 colonic adenomas $(50,54,55,57-59)$. Occurrence of bi-allelic mutations in patients with few to no polyps and early-onset CRC, as well as in CRC-negative individuals but having $<10$ adenomas, 
Table V. Mode of inheritance of hamartomatous polyposis syndromes as well as gene, lifetime risk of cancer development and non-malignant features associated with these syndromes.

\begin{tabular}{|c|c|c|c|c|c|}
\hline Syndrome & Inheritance & Gene & Sites & $\begin{array}{l}\text { Lifetime } \\
\text { risk }(\%)\end{array}$ & Non-malignant features \\
\hline \multirow[t]{9}{*}{ PJS } & Autosomal dominant & STK11 & Breast & 54 & Mucocutaneous pigmentations \\
\hline & & & Colon & 39 & $\begin{array}{l}\text { Gastrointestinal hamartomatous } \\
\text { (Peutz-Jegher) polyps }\end{array}$ \\
\hline & & & Pancreas & $11-36$ & \\
\hline & & & Stomach & 29 & \\
\hline & & & Ovary & 21 & \\
\hline & & & Lung & 15 & \\
\hline & & & Small bowel & 13 & \\
\hline & & & Uterine/cervix & 9 & \\
\hline & & & Testicle & $<1$ & \\
\hline \multirow[t]{2}{*}{ JPS } & Autosomal dominant & SMAD4 & Colon & 39 & $\begin{array}{l}\text { Gastrointestinal hamartomatous } \\
\text { (juvenile) polyps }\end{array}$ \\
\hline & & BMPR1A & $\begin{array}{l}\text { Stomach, pancreas, } \\
\text { and small bowel }\end{array}$ & 21 & $\begin{array}{l}\text { Features of HHT congenital } \\
\text { defects }\end{array}$ \\
\hline
\end{tabular}

PJS, Peutz-Jeghers syndrome; JPS, juvenile polyposis syndrome; HHT, hereditary hemorrhagic telangiectasia.

is rare (60). The presence of MAP is frequent in individuals having 20-90 adenomas $(53,61)$.

Polymerase proofreading-associated polyposis. A new type of polyposis syndrome that is associated with polymerase proofreading, which shows a phenotype including an early onset of colorectal and endometrial cancers along with oligo-adenomatous polyposis, is described in a few families (62). The disease appears to have a high penetrance. Two germline mutations POLE p.Leu424Val and POLDI p.Ser478Asn were identified in individuals with this syndrome. The two pathogenic mutations are characterized by a dominant pattern of inheritance and associated with a high risk of multiple colorectal adenomas, large adenomas, early-onset CRC and multiple CRCs. POLD1 mutations are also associated with increased risk of endometrial cancer in female carriers $(62,63)$.

Most of the germline mutations identified that POLE and POLD1 polymerases are situated in the proofreading (exonuclease) domain of these enzymes, indicating that these mutant polymerases are unable to proofread and repair DNA replication errors $(62,64-66)$. In MSI-positive colorectal and endometrial tumors certain mutations in the non-exonuclease domain of these polymerases and these mutations were found to be passenger mutations (66).

\section{Hamartomatous polyposis syndromes}

Among the hamartomatous polyposis conditions, which confer elevated risk for CRC and other malignancies, JPS and PJS seem to be more important (67), as compared to many other rare hamartomatous polyposis syndromes, such as Cowden syndrome (CS), which pose little risk for CRC.
PJS. PJS patients have multiple hamartomatous polyps, through the GI tract as well as mucocutaneous melanocytic macules. This type of hyperpigmentation is found mostly near the eyes or on the buccal mucosa, nose, or axilla. Other characteristics include small flat, brown, or dark blue spots in the peribuccal area and across the vermillion border of the lips (68). The elevated pigmentation is normally seen in childhood but disappears by adulthood.

The characteristic GI lesions are small bowel, histologically distinctive hamartomatous polyps (69). Gastric and colonic Peutz-Jeghers polyps are found in $\sim 25$ and $30 \%$ of cases, respectively. There is $\sim 87 \%$ lifetime risk of cancer and close to $70 \%$ risk specifically for GI tract cancer in people with PJS (65). In these patients the risk for pancreatic cancer is $11-36 \%$. Other types of cancer are observed (Table V) and nearly $50 \%$ of patients with PJS succumbed to cancer by age 57 years. PJS is inherited in an autosomal-dominant manner with variable penetrance. It arises from mutations of the STK11 gene on chromosome 19p13.3.

$J P S$. JPS is an autosomal-dominantly inherited syndrome and patients with JPS have multiple juvenile polyps in many parts of the GI tract including, colorectum, stomach, jejunum, ileum, and duodenum (67,70-73). Size of the polyps ranges from 5 to $50 \mathrm{~mm}$, and these polyps are spherical and either single or multi-lobulated, with surface erosion. Patients with JPS show symptoms of bleeding, diarrhea, abdominal pain, intussusceptions and rectal prolapse. Because of the overlap with hereditary hemorrhagic telangiectasia (HHT) and arteriovenous shunting, sometimes digital clubbing has been noted in these patients (71).

JPS occurs as a result of mutations of the SMAD4 gene or the BMPRIA gene (73-77). Up to $60 \%$ of individuals with 
clinically defined JPS are now found to exhibit mutations of the SMAD4 or BMPR1A genes (78). Germline mutations in these genes have been identified in $\sim 40 \%$ of JPS patients $(79,80)$. JPS patients with mutations in the SMAD4 gene usually have a family history of upper GI polyposis and are predisposed to developing large gastric polyps $(79,81)$. Patients with $B M P R 1 A$ mutations have a smaller number of gastric polyps compared to patients with $S M A D 4 A(79,81,82)$. A large proportion of JPS patients with SMAD4 mutations have a $39 \%$ lifetime CRC risk, and develop GI juvenile polyps, while JPS patients with $B M P R 1 A$ have a $21 \%$ lifetime risk of extra-colonic cancers and develop an HHT (Table V), a dominant disorder characterized by epistaxis, visceral arteriovenous malformations and telangiectasias (83). In two JPS patients, who did not show any symptoms of hemorrhagic telangiectasia, rare germline mutations in the ENG gene, which confers susceptibility to HHT, have been observed (84). It has been suggested that some patients with PTEN mutations, who have been misclassified as PJS patients, most likely belong to the PTEN hamartoma tumor group $(85,86)$. In these patients, microdeletions at the chromosomal region 10q22-q23, which includes both PTEN and BMPRIA genes, has been reported (87).

CS. CS is associated with a wide range of clinical phenotypes that include orocutaneous lesions. These lesions include palmoplantar keratosis, oral mucosal papillomatosis, and facial trichlemmomas. The patients are at risk of developing cancers of the breast and thyroid. Adenocarcinoma of the uterus may also be associated with the syndrome (88). The majority of patients with CS have polyps throughout the colon $(89,90)$. Hamartomatous polyps are the most common histologic polyps (89). Other polyp types include, juvenile polyps, ganglioneuromas, adenomas, and inflammatory polyps, and less commonly leiomyomas, lipomas, and lymphoid polyps (89-93).

Several investigations report the frequent occurrence of multiple hamartomatous polyps in the stomach, duodenum, and small bowel $(67,89,94)$. The presence of gastric and colon cancers has been reported in some CS patients. CS is caused by germline mutations in the PTEN gene, which is a dual-specific phosphatase associated with the negative regulation of the AKT signaling (95-99).

SPS. SPS is a rare condition with characteristically large and multiple polyps of the colon, with an enhanced risk of CRC. Patients with SPS are a heterogeneous group with different disease phenotypes, which are probably caused by different genetic alterations (100). There are three different subgroups of SPS phenotypes: i) A right-sided phenotype with large sessile serrated adenomas along with an early-onset CRC with $B R A F$ mutation; ii) a left-sided phenotype displaying a high number of small polyps showing KRAS mutation; and iii) a mixed phenotype with the characteristics of phenotypes 1 and $2(100,101)$. Nearly $80 \%$ of patients with SPS display regular colonic adenomas, which are a common occurrence in CRC-affected individuals with SPS $(102,103)$.

Recessive and dominant inheritance patterns have been suggested for the SPS transmittance (104-106). Serrated polyps were observed in patients with bi-allelic mutations in the MUTYH, PTEN, SMAD4, and BMPRIA genes or with duplication in the GREMI gene $(107,108)$. Therefore, these genes were suggested to be altered in individuals with SPS (109). However, the fact that a history of adenomas was reported by 3 patients who meet criteria for SPS in a series of 17 bi-allelic MUTYH mutation carriers, and by one bi-allelic MUTYH mutation carrier among 126 patients with SPS, is indicative of some overlap in the presentation of MAP and SPS.

$H P C$. Despite the fact that there is a genetic risk of pancreatic cancer, the basis for this inheritance is poorly defined. One of the well characterized risk factors for the development of pancreatic cancer is the hereditary chronic recurrent pancreatitis, which has an early onset in life. Both hereditary pancreatitis and age are cumulative factors elevate the relative risk for pancreatic cancer significantly up to 50-fold. Of note, this cumulative risk is found to be higher by as much as $75 \%$, if there is paternal inheritance for pancreatitis. It has been demonstrated that either mutations in PRSS1 gene or a history of pancreatitis have the potential to confer a $5 \%$ risk for tumorigenesis in the same family members (3). Mutations in SPINK1 and CFTR genes, which have been linked to hereditary pancreatitis, may also be associated with elevated risk of pancreatic cancer.

Evidence suggests that germline mutations in $B R C A 2$ gene, which is one of the genes associated with hereditary breast and ovarian cancer, might be the cause of up to $10 \%$ of pancreatic cancer cases $(110,111)$. The 6174de1T BRCA2 mutation, which is found in nearly $1 \%$ of individuals of Ashkenazi Jewish ancestry, likely explains the relatively higher incidence of pancreatic cancer in these people.

A clear genetic correlation between pancreatic cancer and familial melanoma has been described. Thus, patients with a mutation in $C D K N 2 A$ have an elevated risk of both melanoma and pancreatic cancer (112). Whole genome sequencing or linkage analysis of familial pancreatic cancer kindred, have identified palladin (PALLD), ATM, and PALB2 genes, which enhance the risk of pancreatic cancer development (113-116). Apparently, previously known genetic mutations are causative for only $20 \%$ of familial clustering of pancreatic cancer. Therefore, in most cases, the responsible hereditary factors that are responsible for the increased number of pancreatic cancer cases in these kindred have not been identified.

Hereditary gastric cancer. Hereditary diffuse gastric cancer (HDGC) is also inherited in an autosomal dominant manner and develops into a poorly differentiated diffuse gastric adenocarcinoma (117). Clinical presentation of patients generally occurs around 40 years of age with linitis plastica, without a defined gastric tumor. The cumulative risk for the development of gastric cancer by 80 years of age is relatively high in women $(83 \%)$ compared to men $(67 \%)$. Even though no specific area of the stomach is targeted by tumor development, a diffuse area with up to 160 independent foci of tumor have been identified at prophylactic gastrectomy.

Germline mutations in the $\mathrm{CDH} 1$ gene, encoding the transmembrane protein E-cadherin, were found to be the cause of HDGC, with a penetrance of 70-80\% (118). Risk of developing diffuse gastric cancer and lobular breast cancer is enhanced by heterozygous germline mutations in the $C D H 1$ gene. Not all 
families fulfilling these criteria have mutations in $\mathrm{CDH} 1$, indicating that other genes may also be involved in diffuse gastric cancer predisposition. Germline mutations in CTNNA1 gene were described in three families that presented with diffuse gastric cancer (119).

A family history of gastric cancer in the absence of $\mathrm{CDHI}$ mutation, is known as the familial gastric cancer syndrome and can arise due to other inherited cancer predisposition syndromes such FAP and Li-Fraumeni syndrome (which is due to germline mutations in the TP53 tumor suppressor gene). Lynch syndrome confers $\sim 13 \%$ risk for gastric cancer and inherited germline $B R C A 2$ mutations also confer a great risk. A specific $B R C A 2,614$ de1T, has been reportedly associated with a risk of gastric cancer by $\sim 5.7 \%$ (120). It is important to bear in mind that nearly $21 \%$ patients with a family history of breast or gastric cancers, have BRCA2 mutation. BRCA2 mutations are also noted in $24 \%$ of the patients with a family history of ovarian and gastric cancer (121).

\section{Conclusion}

Several well established hereditary GI cancer syndromes now exist, each with implication for specific cancer risk in GI and other organ systems. Investigation of the causative genetic factors has led to the identification of specific germline mutations for several syndromes. Understanding the effect of these mutations in susceptibility is of great importance for cancer research aimed at developing new therapeutic and preventive strategies. Although there are numerous gaps in current knowledge related to certain hereditary GI cancer syndromes, it is not unreasonable to assume that studies of GI syndromes may continue to lead the field in cancer research.

\section{References}

1. Grady WM and Markowitz SD: Genetic and epigenetic alterations in colon cancer. Annu Rev Genomics Hum Genet 3: 101-128, 2002.

2. Garber JE and Offit K: Hereditary cancer predisposition syndromes. J Clin Oncol 23: 276-292, 2005.

3. Jasperson KW, Tuohy TM, Neklason DW and Burt RW: Hereditary and familial colon cancer. Gastroenterology 138: 2044-2058, 2010.

4. Oliveira C, Seruca R and Carneiro F: Genetics, pathology, and clinics of familial gastric cancer. Int J Surg Pathol 14: 21-33, 2006.

5. Entius MM, Keller JJ, Westerman AM, van Rees BP, van Velthuysen ML, de Goeij AF, Wilson JH, Giardiello FM and Offerhaus GJ: Molecular genetic alterations in hamartomatous polyps and carcinomas of patients with Peutz-Jeghers syndrome. J Clin Pathol 54: 126-131, 2001.

6. Torrezan GT, da Silva FC, Santos EM, Krepischi AC, Achatz MI, Aguiar S Jr, Rossi BM and Carraro DM: Mutational spectrum of the APC and MUTYH genes and genotype-phenotype correlations in Brazilian FAP, AFAP, and MAP patients. Orphanet J Rare Dis 8: 54, 2013.

7. Attard TM, Abraham SC and Cuffari C: The clinical spectrum of duodenal polyps in pediatrics. J Pediatr Gastroenterol Nutr 36: $116-119,2003$

8. Aarnio M, Sankila R, Pukkala E, Salovaara R, Aaltonen LA, de la Chapelle A, Peltomäki P, Mecklin JP and Järvinen HJ: Cancer risk in mutation carriers of DNA-mismatch-repair genes. Int J Cancer 81: 214-218, 1999.

9. Rowley PT: Inherited susceptibility to colorectal cancer. Annu Rev Med 56: 539-554, 2005.

10. Stoffel E, Mukherjee B, Raymond VM, Tayob N, Kastrinos F, Sparr J, Wang F, Bandipalliam P, Syngal S and Gruber SB: Calculation of risk of colorectal and endometrial cancer among patients with Lynch syndrome. Gastroenterology 137: $1621-1627,2009$.
11. Lynch HT, Lynch PM, Lanspa SJ, Snyder CL, Lynch JF and Boland CR: Review of the Lynch syndrome: history, molecular genetics, screening, differential diagnosis, and medicolegal ramifications. Clin Genet 76: 1-18, 2009.

12. Douglas JA, Gruber SB, Meister KA, Bonner J, Watson P, Krush AJ and Lynch HT: History and molecular genetics of Lynch syndrome in family G: a century later. JAMA 294: 2195-2202, 2005.

13. Lynch HT and de la Chapelle A: Hereditary colorectal cancer. N Engl J Med 348: 919-932, 2003.

14. Lynch HT and Lynch J: Lynch syndrome: genetics, natural history, genetic counseling, and prevention. J Clin Oncol 18 (Suppl 21): 19S-31S, 2000.

15. Gruber SB: New developments in Lynch syndrome (hereditary nonpolyposis colorectal cancer) and mismatch repair gene testing. Gastroenterology 130: 577-587, 2006.

16. Lu KH and Broaddus RR: Gynecologic cancers in lynch syndrome/hnpcc. Fam Cancer 4: 249-254, 2005.

17. Hampel H, Frankel W, Panescu J, Lockman J, Sotamaa K, Fix D, Comeras I, La Jeunesse J, Nakagawa H, Westman JA, et al: Screening for Lynch syndrome (hereditary nonpolyposis colorectal cancer) among endometrial cancer patients. Cancer Res 66: 7810-7817, 2006.

18. Eng C, Hampel $\mathrm{H}$ and de la Chapelle A: Genetic testing for cancer predisposition. Annu Rev Med 52: 371-400, 2001.

19. Lindor NM, Petersen GM, Hadley DW, Kinney AY, Miesfeldt S, Lu KH, Lynch P, Burke W and Press N: Recommendations for the care of individuals with an inherited predisposition to Lynch syndrome: a systematic review. JAMA 296: 1507-1517, 2006.

20. Peltomäki P: Lynch syndrome genes. Fam Cancer 4: 227-232, 2005.

21. Vasen HF: Clinical description of the Lynch syndrome [hereditary nonpolyposis colorectal cancer (HNPCC)]. Fam Cancer 4: 219-225, 2005.

22. Hampel H and Peltomaki P: Hereditary colorectal cancer: risk assessment and management. Clin Genet 58: 89-97, 2000.

23. Lynch HT and Smyrk T: Hereditary nonpolyposis colorectal cancer (Lynch syndrome). An updated review. Cancer 78: 1149-1167, 1996.

24. Lynch HT, Smyrk T and Lynch JF: Molecular genetics and clinical-pathology features of hereditary nonpolyposis colorectal carcinoma (Lynch syndrome): historical journey from pedigree anecdote to molecular genetic confirmation. Oncology 55: 103-108, 1998

25. Guillem JG, Wood WC, Moley JF, Berchuck A, Karlan BY, Mutch DG, Gagel RF, Weitzel J, Morrow M, Weber BL, et al; ASCO; SSO: ASCO/SSO review of current role of risk-reducing surgery in common hereditary cancer syndromes. J Clin Oncol 24: 4642-4660, 2006.

26. Lynch HT, Lynch JF. What the physician needs to know about Lynch syndrome: an update. Oncology (Williston Park) 19: 455-463; discussion 463-454, 466, 469, 2005.

27. Ribic CM, Sargent DJ, Moore MJ, Thibodeau SN, French AJ, Goldberg RM, Hamilton SR, Laurent-Puig P, Gryfe R, Shepherd LE, et al: Tumor microsatellite-instability status as a predictor of benefit from fluorouracil-based adjuvant chemotherapy for colon cancer. N Engl J Med 349: 247-257, 2003

28. Boland CR, Thibodeau SN, Hamilton SR, Sidransky D, Eshleman JR, Burt RW, Meltzer SJ, Rodriguez-Bigas MA, Fodde R, Ranzani GN, et al: A National Cancer Institute Workshop on Microsatellite Instability for cancer detection and familial predisposition: development of international criteria for the determination of microsatellite instability in colorectal cancer. Cancer Res 58: 5248-5257, 1998.

29. Cunningham JM, Kim CY, Christensen ER, Tester DJ, Parc Y, Burgart LJ, Halling KC, McDonnell SK, Schaid DJ, Walsh Vockley C, et al: The frequency of hereditary defective mismatch repair in a prospective series of unselected colorectal carcinomas. Am J Hum Genet 69: 780-790, 2001.

30. Rustgi AK: The genetics of hereditary colon cancer. Genes Dev 21: 2525-2538, 2007.

31. Peltomäki P and Vasen $\mathrm{H}$ : Mutations associated with HNPCC predisposition - Update of ICG-HNPCC/INSiGHT mutation database. Dis Markers 20: 269-276, 2004.

32. Plaschke J, Engel C, Krüger S, Holinski-Feder E, Pagenstecher C, Mangold E, Moeslein G, Schulmann K, Gebert J, von Knebel Doeberitz M, et al: Lower incidence of colorectal cancer and later age of disease onset in 27 families with pathogenic $M S H 6$ germline mutations compared with families with $M L H 1$ or $M S H 2$ mutations: the German Hereditary Nonpolyposis Colorectal Cancer Consortium. J Clin Oncol 22: 4486-4494, 2004. 
33. Senter L, Clendenning M, Sotamaa K, Hampel H, Green J, Potter JD, Lindblom A, Lagerstedt K, Thibodeau SN, Lindor NM, et al: The clinical phenotype of Lynch syndrome due to germ-line PMS2 mutations. Gastroenterology 135 419-428, 2008

34. Bülow S: Familial polyposis coli. Dan Med Bull 34: 1-15, 1987.

35. Giardiello FM, Brensinger JD and Petersen GM: AGA technical review on hereditary colorectal cancer and genetic testing. Gastroenterology 121: 198-213, 2001.

36. Soravia C, Berk T, McLeod RS and Cohen Z: Desmoid disease in patients with familial adenomatous polyposis. Dis Colon Rectum 43: 363-369, 2000

37. Belchetz LA, Berk T, Bapat BV, Cohen Z and Gallinger S: Changing causes of mortality in patients with familial adenomatous polyposis. Dis Colon Rectum 39: 384-387, 1996

38. Cetta F, Montalto G, Gori M, Curia MC, Cama A and Olschwang S: Germline mutations of the APC gene in patients with familial adenomatous polyposis-associated thyroid carcinoma: results from a European cooperative study. J Clin Endocrinol Metab 85: 286-92, 2000.

39. Fearon ER and Vogelstein B: A genetic model for colorectal tumorigenesis. Cell 61: 759-767, 1990

40. Kinzler KW and Vogelstein B: Lessons from hereditary colorectal cancer. Cell 87: 159-170, 1996.

41. Bisgaard ML, Fenger K, Bülow S, Niebuhr E and Mohr J: Familial adenomatous polyposis (FAP): frequency, penetrance, and mutation rate. Hum Mutat 3: 121-125, 1994.

42. Hes FJ, Nielsen M, Bik EC, Konvalinka D, Wijnen JT, Bakker E, Vasen HF, Breuning MH and Tops CM: Somatic APC mosaicism: an underestimated cause of polyposis coli. Gut 57: 71-76, 2008.

43. Nieuwenhuis MH and Vasen HF: Correlations between mutation site in APC and phenotype of familial adenomatous polyposis (FAP): a review of the literature. Crit Rev Oncol Hematol 61: 153-161, 2007.

44. Galiatsatos P and Foulkes WD: Familial adenomatous polyposis Am J Gastroenterol 101: 385-398, 2006.

45. Laken SJ, Petersen GM, Gruber SB, Oddoux C, Ostrer H, Giardiello FM, Hamilton SR, Hampel H, Markowitz A, Klimstra D, et al: Familial colorectal cancer in Ashkenazim due to a hypermutable tract in APC. Nat Genet 17: 79-83, 1997.

46. Gryfe R, Di Nicola N, Lal G, Gallinger S and Redston M: Inherited colorectal polyposis and cancer risk of the APC I1307K polymorphism. Am J Hum Genet 64: 378-384, 1999.

47. Claes K, Dahan K, Tejpar S, De Paepe A, Bonduelle M, Abramowicz M, Verellen C, Franchimont D, Van Cutsem $\mathrm{E}$ and Kartheuser A: The genetics of familial adenomatous polyposis (FAP) and MutYH-associated polyposis (MAP). Acta Gastroenterol Belg 74: 421-426, 2011.

48. Al-Tassan N, Chmiel NH, Maynard J, Fleming $\mathrm{N}$, Livingston AL, Williams GT, Hodges AK, Davies DR, David SS Sampson JR, et al: Inherited variants of $M Y H$ associated with somatic G:C-->T:A mutations in colorectal tumors. Nat Genet 30 : 227-232, 2002

49. Lefevre JH, Parc Y, Svrcek M, Kernéis S, Colas C, Shields C, Flejou JF, Parc R and Tiret E: APC, MYH, and the correlation genotype-phenotype in colorectal polyposis. Ann Surg Oncol 16: 871-877, 2009

50. Morak M, Laner A, Bacher U, Keiling C and Holinski-Feder E: MUTYH-associated polyposis - variability of the clinical phenotype in patients with biallelic and monoallelic MUTYH mutations and report on novel mutations. Clin Genet 78 : 353-363, 2010

51. Out AA, Tops CM, Nielsen M, Weiss MM, van Minderhout IJ, Fokkema IF, Buisine MP, Claes K, Colas C, Fodde R, et al: Leiden open variation database of the MUTYH gene. Hum Mutat 31: 1205-1215, 2010.

52. Cleary SP, Cotterchio M, Jenkins MA, Kim H, Bristow R, Green R, Haile R, Hopper JL, LeMarchand L, Lindor N, et al: Germline MutY human homologue mutations and colorectal cancer: a multisite case-control study. Gastroenterology 136: $1251-1260,2009$

53. Nielsen M, Joerink-van de Beld MC, Jones N, Vogt S, Tops CM, Vasen HF, Sampson JR, Aretz S and Hes FJ: Analysis of MUTYH genotypes and colorectal phenotypes in patients with MUTYH-associated polyposis. Gastroenterology 136: 471-476, 2009.

54. Sieber OM, Lipton L, Crabtree M, Heinimann K, Fidalgo P, Phillips RK, Bisgaard ML, Orntoft TF, Aaltonen LA, Hodgson SV, et al: Multiple colorectal adenomas, classic adenomatous polyposis, and germ-line mutations in MYH. N Engl J Med 348: 791-799, 2003.
55. Lipton L and Tomlinson I: The multiple colorectal adenoma phenotype and $M Y H$, a base excision repair gene. Clin Gastroenterol Hepatol 2: 633-638, 2004.

56. Halford SE, Rowan AJ, Lipton L, Sieber OM, Pack K, Thomas HJ, Hodgson SV, Bodmer WF and Tomlinson IP Germline mutations but not somatic changes at the MYH locus contribute to the pathogenesis of unselected colorectal cancers. Am J Pathol 162: 1545-1548, 2003.

57. Nielsen M, Morreau H, Vasen HFand Hes FJ: MUTYH-associated polyposis (MAP). Crit Rev Oncol Hematol 79: 1-16, 2011.

58. Jones S, Emmerson P, Maynard J, Best JM, Jordan S, Williams GT, Sampson JR and Cheadle JP: Biallelic germline mutations in $M Y H$ predispose to multiple colorectal adenoma and somatic G:C-->T:A mutations. Hum Mol Genet 11: 2961-2967, 2002.

59. Sampson JR, Dolwani S, Jones S, Eccles D, Ellis A, Evans DG, Frayling I, Jordan S, Maher ER, Mak T, et al: Autosomal recessive colorectal adenomatous polyposis due to inherited mutations of $M Y H$. Lancet 362: 39-41, 2003.

60. Enholm S, Hienonen T, Suomalainen A, Lipton L, Tomlinson I, Kärjä V, Eskelinen M, Mecklin JP, Karhu A, Järvinen HJ, et al: Proportion and phenotype of $M Y H$-associated colorectal neoplasia in a population-based series of Finnish colorectal cancer patients. Am J Pathol 163: 827-832, 2003.

61. Wang L, Baudhuin LM, Boardman LA, Steenblock KJ, Petersen GM, Halling KC, French AJ, Johnson RA, Burgart LJ, Rabe K, et al: $M Y H$ mutations in patients with attenuated and classic polyposis and with young-onset colorectal cancer without polyps. Gastroenterology 127: 9-16, 2004.

62. Jo WS, Bandipalliam P, Shannon KM, Niendorf KB, Chan-Smutko G, Hur C, Syngal S and Chung DC: Correlation of polyp number and family history of colon cancer with germline MYH mutations. Clin Gastroenterol Hepatol 3: 1022-1028, 2005.

63. Venesio T, Molatore S, Cattaneo F, Arrigoni A, Risio M and Ranzani GN: High frequency of $M Y H$ gene mutations in a subset of patients with familial adenomatous polyposis. Gastroenterology 126: 1681-1685, 2004.

64. Knopperts AP, Nielsen M, Niessen RC, Tops CM, Jorritsma B, Varkevisser J, Wijnen J, Siezen CL, Heine-Bröring RC, van Kranen $\mathrm{HJ}$, et al: Contribution of bi-allelic germline MUTYH mutations to early-onset and familial colorectal cancer and to low number of adenomatous polyps: case-series and literature review. Fam Cancer 12: 43-50, 2013.

65. Filipe B, Baltazar C, Albuquerque C, Fragoso S, Lage P, Vitoriano I, Mão de Ferro S, Claro I, Rodrigues P, Fidalgo P, et al: APC or MUTYH mutations account for the majority of clinically well-characterized families with FAP and AFAP phenotype and patients with more than 30 adenomas. Clin Genet 76 : 242-255, 2009.

66. Palles C, Cazier JB, Howarth KM, Domingo E, Jones AM, Broderick P, Kemp Z, Spain SL, Guarino E, Salguero I, et al; WGS500 Consortium: Germline mutations affecting the proofreading domains of POLE and POLD1 predispose to colorectal adenomas and carcinomas. Nat Genet 45: 136-144, 2013.

67. Valle L, Hernández-Illán E, Bellido F, Aiza G, Castillejo A, Castillejo MI, Navarro M, Seguí N, Vargas G, Guarinos C, et al: New insights into POLE and POLD1 germline mutations in familial colorectal cancer and polyposis. Hum Mol Genet 23: 3506-3512, 2014

68. Jenne DE, Reimann H, Nezu J, Friedel W, Loff S, Jeschke R, Müller O, Back W and Zimmer M: Peutz-Jeghers syndrome is caused by mutations in a novel serine threonine kinase. Nat Genet 18: 38-43, 1998.

69. Donehower LA, Creighton CJ, Schultz N, Shinbrot E, Chang K, Gunaratne PH, Muzny D, Sander C, Hamilton SR, Gibbs RA, et al: $M L H 1$-silenced and non-silenced subgroups of hypermutated colorectal carcinomas have distinct mutational landscapes. J Pathol 229: 99-110, 2013.

70. Church DN, Briggs SE, Palles C, Domingo E, Kearsey SJ, Grimes JM, Gorman M, Martin L, Howarth KM, Hodgson SV, et al; NSECG Collaborators: DNA polymerase $\varepsilon$ and $\delta$ exonuclease domain mutations in endometrial cancer. Hum Mol Genet 22: 2820-2828, 2013.

71. Briggs S and Tomlinson I: Germline and somatic polymerase $\varepsilon$ and $\delta$ mutations define a new class of hypermutated colorectal and endometrial cancers. J Pathol 230: 148-153, 2013.

72. Schreibman IR, Baker M, Amos C and McGarrity TJ: The hamartomatous polyposis syndromes: a clinical and molecular review. Am J Gastroenterol 100: 476-490, 2005.

73. McGarrity TJ and Amos C: Peutz-Jeghers syndrome: clinicopathology and molecular alterations. Cell Mol Life Sci 63: 2135-2144, 2006 
74. Gammon A, Jasperson K, Kohlmann W and Burt RW: Hamartomatous polyposis syndromes. Best Pract Res Clin Gastroenterol 23: 219-231, 2009.

75. Chow E and Macrae F: A review of juvenile polyposis syndrome. J Gastroenterol Hepatol 20: 1634-1640, 2005.

76. Boardman LA: Heritable colorectal cancer syndromes: recognition and preventive management. Gastroenterol Clin North Am 31: 1107-1131, 2002.

77. Latchford AR, Neale K, Phillips RK and Clark SK: Juvenile polyposis syndrome: a study of genotype, phenotype, and long-term outcome. Dis Colon Rectum 55: 1038-1043, 2012.

78. Howe JR, Bair JL, Sayed MG, Anderson ME, Mitros FA, Petersen GM, Velculescu VE, Traverso G and Vogelstein B Germline mutations of the gene encoding bone morphogenetic protein receptor $1 \mathrm{~A}$ in juvenile polyposis. Nat Genet 28 $184-187,2001$

79. Howe JR, Ringold JC, Summers RW, Mitros FA, Nishimura DY and Stone EM: A gene for familial juvenile polyposis maps to chromosome 18q21.1. Am J Hum Genet 62: 1129-1136, 1998.

80. Howe JR, Roth S, Ringold JC, Summers RW, Järvinen HJ, Sistonen P, Tomlinson IP, Houlston RS, Bevan S, Mitros FA, et al: Mutations in the SMAD4/DPC4 gene in juvenile polyposis. Science 280: 1086-1088, 1998.

81. Zhou XP, Woodford-Richens K, Lehtonen R, Kurose K, Aldred M, Hampel H, Launonen V, Virta S, Pilarski R, Salovaara R, et al: Germline mutations in BMPR1A/ALK3 cause a subset of cases of juvenile polyposis syndrome and of Cowden and Bannayan-Riley-Ruvalcaba syndromes. Am J Hum Genet 69: 704-711, 2001.

82. Aretz S, Stienen D, Uhlhaas S, Stolte M, Entius MM, Loff S, Back W, Kaufmann A, Keller KM, Blaas SH, et al: High proportion of large genomic deletions and a genotype phenotype update in 80 unrelated families with juvenile polyposis syndrome. J Med Genet 44: 702-709, 2007.

83. Sayed MG, Ahmed AF, Ringold JR, Anderson ME, Bair JL, Mitros FA, Lynch HT, Tinley ST, Petersen GM, Giardiello FM, et al: Germline SMAD4 or BMPR1A mutations and phenotype of juvenile polyposis. Ann Surg Oncol 9: 901-906, 2002

84. Howe JR, Sayed MG, Ahmed AF, Ringold J, Larsen-Haidle J, Merg A, Mitros FA, Vaccaro CA, Petersen GM, Giardiello FM, et al: The prevalence of MADH4 and BMPRIA mutations in juvenile polyposis and absence of $B M P R 2, B M P R 1 B$, and $A C V R 1$ mutations. J Med Genet 41: 484-491, 2004.

85. Friedl W, Uhlhaas S, Schulmann K, Stolte M, Loff S, Back W, Mangold E, Stern M, Knaebel HP, Sutter C, et al: Juvenile polyposis: massive gastric polyposis is more common in MADH4 mutation carriers than in BMPRIA mutation carriers. Hum Genet 111: 108-111, 2002.

86. Handra-Luca A, Condroyer C, de Moncuit C, Tepper M, Fléjou JF, Thomas G and Olschwang S: Vessels' morphology in SMAD4 and BMPR1A-related juvenile polyposis. Am J Med Genet A 138A: 113-117, 2005.

87. O'Malley M, LaGuardia L, Kalady MF, Parambil J, Heald B, Eng C, Church J and Burke CA: The prevalence of hereditary hemorrhagic telangiectasia in juvenile polyposis syndrome. Dis Colon Rectum 55: 886-892, 2012.

88. Sweet K, Willis J, Zhou XP, Gallione C, Sawada T, Alhopuro P, Khoo SK, Patocs A, Martin C, Bridgeman S, et al: Molecular classification of patients with unexplained hamartomatous and hyperplastic polyposis. JAMA 294: 2465-2473, 2005.

89. van Hattem WA, Brosens LA, de Leng WW, Morsink FH, Lens S, Carvalho R, Giardiello FM and Offerhaus GJ: Large genomic deletions of SMAD4, BMPRIA and PTEN in juvenile polyposis Gut 57: 623-627, 2008.

90. Eng $\mathrm{C}$ and Ji H: Molecular classification of the inherited hamartoma polyposis syndromes: clearing the muddied waters. Am J Hum Genet 62: 1020-1022, 1998.

91. Dahdaleh FS, Carr JC, Calva D and Howe JR: Juvenile polyposis and other intestinal polyposis syndromes with microdeletions of chromosome 10q22-23. Clin Genet 81: 110-116, 2012.

92. Starink TM, van der Veen JP, Arwert F, de Waal LP, de Lange GG, Gille JJ and Eriksson AW: The Cowden syndrome: a clinical and genetic study in 21 patients. Clin Genet 29: 222-233, 1986.

93. Heald B, Mester J, Rybicki L, Orloff MS, Burke CA and Eng C: Frequent gastrointestinal polyps and colorectal adenocarcinomas in a prospective series of PTEN mutation carriers. Gastroenterology 139: 1927-1933, 2010
94. Stanich PP, Owens VL, Sweetser S, Khambatta S, Smyrk TC, Richardson RL, Goetz MP and Patnaik MM: Colonic polyposis and neoplasia in Cowden syndrome. Mayo Clin Proc 86: 489-492, 2011

95. Trufant JW, Greene L, Cook DL, McKinnon W, Greenblatt M and Bosenberg MW: Colonic ganglioneuromatous polyposis and metastatic adenocarcinoma in the setting of Cowden syndrome: a case report and literature review. Hum Pathol 43: 601-604, 2012

96. Levi Z, Baris HN, Kedar I, Niv Y, Geller A, Gal E, Gingold R, Morgenstern S, Baruch Y, Leach BH, et al: Upper and lower gastrointestinal findings in pten mutation-positive cowden syndrome patients participating in an active surveillance program. Clin Transl Gastroenterol 2: e5, 2011.

97. Pilarski R: Cowden syndrome: a critical review of the clinical literature. J Genet Couns 18: 13-27, 2009.

98. McGarrity TJ, Wagner Baker MJ, Ruggiero FM, Thiboutot DM, Hampel H, Zhou XP and Eng C: GI polyposis and glycogenic acanthosis of the esophagus associated with PTEN mutation positive Cowden syndrome in the absence of cutaneous manifestations. Am J Gastroenterol 98: 1429-1434, 2003.

99. Liaw D, Marsh DJ, Li J, Dahia PL, Wang SI, Zheng Z, Bose S, Call KM, Tsou HC, Peacocke M, et al: Germline mutations of the PTEN gene in Cowden disease, an inherited breast and thyroid cancer syndrome. Nat Genet 16: 64-67, 1997.

100. Nelen MR, Padberg GW, Peeters EA, Lin AY, van den Helm B, Frants RR, Coulon V, Goldstein AM, van Reen MM, Easton DF, et al: Localization of the gene for Cowden disease to chromosome 10q22-23. Nat Genet 13: 114-116, 1996.

101. Nelen MR, van Staveren WC, Peeters EA, Hassel MB, Gorlin RJ, Hamm H, Lindboe CF, Fryns JP, Sijmons RH, Woods DG, et al: Germline mutations in the PTEN/MMACl gene in patients with Cowden disease. Hum Mol Genet 6: 1383-1387, 1997.

102. Lynch ED, Ostermeyer EA, Lee MK, Arena JF, Ji H, Dann J, Swisshelm K, Suchard D, MacLeod PM, Kvinnsland S, et al: Inherited mutations in PTEN that are associated with breast cancer, cowden disease, and juvenile polyposis. Am J Hum Genet 61: 1254-1260, 1997.

103. Stambolic V, Suzuki A, de la Pompa JL, Brothers GM, Mirtsos C, Sasaki T, Ruland J, Penninger JM, Siderovski DP and Mak TW: Negative regulation of PKB/Akt-dependent cell survival by the tumor suppressor PTEN. Cell 95: 29-39, 1998.

104. Kalady MF, Jarrar A, Leach B, LaGuardia L, O'Malley M, Eng $\mathrm{C}$ and Church JM: Defining phenotypes and cancer risk in hyperplastic polyposis syndrome. Dis Colon Rectum 54: 164-170, 2011

105. Carvajal-Carmona LG, Howarth KM, Lockett M, Polanco-Echeverry GM, Volikos E, Gorman M, Barclay E, Martin L, Jones AM, Saunders B, et al: Molecular classification and genetic pathways in hyperplastic polyposis syndrome. J Pathol 212: 378-385, 2007.

106. Buchanan DD, Sweet K, Drini M, Jenkins MA, Win AK, English DR, Walsh MD, Clendenning M, McKeone DM, Walters RJ, et al: Risk factors for colorectal cancer in patients with multiple serrated polyps: a cross-sectional case series from genetics clinics. PLoS One 5: e11636, 2010.

107. Buchanan DD, Sweet K, Drini M, Jenkins MA, Win AK, Gattas M, Walsh MD, Clendenning M, McKeone D, Walters R, et al: Phenotypic diversity in patients with multiple serrated polyps: a genetics clinic study. Int J Colorectal Dis 25: 703-712, 2010 .

108. Chow E, Lipton L, Lynch E, D'Souza R, Aragona C, Hodgkin L, Brown G, Winship I, Barker M, Buchanan D, et al: Hyperplastic polyposis syndrome: phenotypic presentations and the role of MBD4 and MYH. Gastroenterology 131: 30-39, 2006.

109. Young $\mathbf{J}$ and Jass JR: The case for a genetic predisposition to serrated neoplasia in the colorectum: hypothesis and review of the literature. Cancer Epidemiol Biomarkers Prev 15: 1778-1784, 2006.

110. Boparai KS, Dekker E, Van Eeden S, Polak MM, Bartelsman JF, Mathus-Vliegen EM, Keller JJ and van Noesel CJ: Hyperplastic polyps and sessile serrated adenomas as a phenotypic expression of MYH-associated polyposis. Gastroenterology 135: 2014-2018, 2008.

111. Mongin C, Coulet F, Lefevre JH, Colas C, Svrcek M, Eyries M, Lahely Y, Fléjou JF, Soubrier F and Parc Y: Unexplained polyposis: a challenge for geneticists, pathologists and gastroenterologists. Clin Genet 81: 38-46, 2012. 
112. Clendenning M, Young JP, Walsh MD, Woodall S, Arnold J, Jenkins M, Win AK, Hopper JL, Sweet K, Gallinger S, et al: Germline mutations in the polyposis-associated genes, and are not common in individuals with serrated polyposis syndrome. PLoS One 8: e66705, 2013.

113. Rebours V, Boutron-Ruault MC, Schnee M, Férec C, Maire F, Hammel P, Ruszniewski P and Lévy P: Risk of pancreatic adenocarcinoma in patients with hereditary pancreatitis: a national exhaustive series. Am J Gastroenterol 103: 111-119, 2008.

114. Greer JB, Whitcomb DC and Brand RE: Genetic predisposition to pancreatic cancer: a brief review. Am J Gastroenterol 102: 2564-2569, 2007.

115. Goggins M, Schutte M, Lu J, Moskaluk CA, Weinstein CL, Petersen GM, Yeo CJ, Jackson CE, Lynch HT, Hruban RH, et al: Germline $B R C A 2$ gene mutations in patients with apparently sporadic pancreatic carcinomas. Cancer Res 56:5360-5364, 1996.

116. Chapman PB: Melanoma vaccines. Semin Oncol 34: 516-523, 2007.

117. Pogue-Geile KL, Chen R, Bronner MP, Crnogorac-Jurcevic T, Moyes KW, Dowen S, Otey CA, Crispin DA, George RD, Whitcomb DC, et al: Palladin mutation causes familial pancreatic cancer and suggests a new cancer mechanism. PLoS Med 3: e516, 2006.
118. Roberts NJ, Jiao Y, Yu J, Kopelovich L, Petersen GM, Bondy ML, Gallinger S, Schwartz AG, Syngal S, Cote ML, et al: ATM mutations in patients with hereditary pancreatic cancer. Cancer Discov 2: 41-46, 2012.

119. Harinck F, Kluijt I, van Mil SE, Waisfisz Q, van Os TA, Aalfs CM, Wagner A, Olderode-Berends M, Sijmons RH, Kuipers EJ, et al: Routine testing for PALB2 mutations in familial pancreatic cancer families and breast cancer families with pancreatic cancer is not indicated. Eur J Hum Genet 20: $577-579,2012$

120. Jones S, Hruban RH, Kamiyama M, Borges M, Zhang X, Parsons DW, Lin JC, Palmisano E, Brune K, Jaffee EM, et al: Exomic sequencing identifies $P A L B 2$ as a pancreatic cancer susceptibility gene. Science 324: 217, 2009.

121. Huntsman DG, Carneiro F, Lewis FR, MacLeod PM, Hayashi A, Monaghan KG, Maung R, Seruca R, Jackson CE and Caldas C: Early gastric cancer in young, asymptomatic carriers of germ-line E-cadherin mutations. N Engl J Med 344: 1904-1909, 2001. 